短

報

\section{アシノワハダニのセイタカアワダチソウ における越冬生態}

\author{
望 月 雅 俊1) \\ 京都大学農学部
}

\begin{abstract}
Overwintering Ecology of Desert Spider Mite (Tetranychus desertorum BANKs) on Goldenrod (Solidago altissima L.). Masatoshi Mochizuki ${ }^{2)}$ (Kyoto University, Kyoto 606, Japan). Jpn. J. Appl. Ent. Zool. 32: 143-146 (1988)
\end{abstract}

Abstract: As the parent plants withered in autumn, adult females moved to the rosette. Throughout the winter, all stages of $T$. desertorum were observed on the rosette, and adult females survived winter without entering diapause. Laboratory experiments also confirmed the non-diapausing nature of this population.

$$
\text { 緒気 }
$$

アシノワハダニ Tetranychus desertorum BANKs はナスやイチゴ などの栽培植物 (小林・深沢，1981）のほか, 各種の雑草にも発 生し, これらの寄主植物の一つとしてセイタカアワダチソウが ある。この植物上で, 本種は春から秋にかけて, 二山あるいは 三山型の季節消長を示す (TAKAFUJI, 1980)。さらに，本種の場 合, 初冬拉よび早春にはセイタカアワダチソウのロゼットから も雌成虫が採集されるため (TAKAFUJI, 1980)，冬季もこの寄主 上で越冬する個体群が存在すると思われる。ただ，わが国での 本種の越冬生態についてはこれまで報告がなく，また，その休 眠性についても調べられていない。そこで, 本研究では秋から 春にかけて，七イタカアワダチソウ群落で本種の越冬生態を調 査し,さらに室内実験で，その休眠性も調べた。

本文に入るに先立ち，本稿のご校閲をいただいた高藤晃雄京 都大学助教授に御礼申し上げる。

\section{材料および方法}

調查は京都府宇治市宇治川堤防のセイタカアワダチソウ Solidago altissima L. 群落で 1985 年 9 月から翌年 4 月まで月 2 回の頻度で行った。この群落では少なくとも過去 10 年以上にわ たってアシノワハダ二の発生が継続している。

長さ約 $50 \mathrm{~m}$, 幅 $0.1 \sim 0.5 \mathrm{~m}$ の列状の群落に $10 \mathrm{~m}$ おきに長
さ $1 \mathrm{~m}$ の調查区を五つ設定し, 花序をつけた親株と地際に生え るロゼットの株数を全数調査した。これらの株数調查区以外か らは，ロゼットと親株をそれぞれ 50 株ずつランダムに抽出し， ロゼットについては全葉を，また親株については，さらに 1 株 あたり 10 葉ずつをランダム抽出して計 500 葉を実体顕微鏡下 で観察し，八ダニ数をステージごとに記録した。また，成虫の 性比も同時に調查した。

㛜冬期に採集した卵は，その生存率を調べるため，シャーレ 内の湿った脱脂綿上に卵の付着した葉片を置き， $25^{\circ} \mathrm{C}: 16 \mathrm{~L}$ で 7 日間加温して餒化率を調べた。

調查期間中，毎回採集された 雌成虫が休眠状態にあるかどう かを確かめるため, $25^{\circ} \mathrm{C}: 16 \mathrm{~L}$ で 5 日間加温し産卵の有無を調 べた。さらに，1985年 4 月に同じ場所で採集した本種をインゲ ンマメ Phaseolus vulgaris $\mathrm{L}$. を用い $20^{\circ} \mathrm{C}: 16 \mathrm{~L}$ で 2 か月間累代 飼育した後, 後藤・真梶 (1980) の方法に従い, $15^{\circ} \mathrm{C}: 9 \mathrm{~L}$ で卵 から成虫まで飼育して個体別に休眠性を調べた。なお，調查卵 数は 58 であった。

結果

親株は 10 月中旬から11月上旬にかけて開花した。その後, 徐 徐に葉数が減少し 1 月上旬までにすべて枯死した。一方，口ゼ ットの株数は 11 月以降漸次増加し， 3 月には調查区画内に 300 株程度が観察された (Fig. 1)。

調查期間中 12 月から 2 月にかけての観察では, 七イタカアワ ダチソウのロゼット以外の雑草はほとんど見られなかった。

葉あたり雌成虫数, 齢構成抢よび性比の季節的变化は親株と ロゼットで大きく異なった。親株では，葉あたり雌成虫数，龄 構成抢上び性比の季節的変化は親株と口ゼットで大きく異なっ た。親株では，葉あたり雌成虫数は調查開始時を除けば一葉あ たり 0.1 以下の低密度で枮死するまで推移し (Fig. 2), 卵の割 合は親株が枯死する直前の 12 月下旬には $10 \%$ にまで減少した (Fig. 3)。また，この間に性比はしだいに雄に偏っていった (Fig. 4)。

一方，口ゼット葉上の雌成虫数は秋から急増し，12月下旬に ピークに達した。その後，3月下旬まで減少を続け，これに対 态して 1 月から 3 月にかけては毎調查時に 10 30 個体の死亡 雌成虫が観察された (Fig. 2)。龄構成および性比は調查期間を 通じて安定し, 卵の比率は常に $70 \%$ 以上 (Fig. 3), 雌比も 0.7 から 0.8 であった (Fig. 4)。さらに厳冬期の卵の睬化率は 2 月 上旬には $38 \%$ まで低下したが，これ以外では $70 \%$ 程度の餒化 率が維持された (Fig. 5)。

各調查時に採集した雌成虫は加温後すみやかに産卵を開始し, 産卵までの期間は採集時期に関係なく短かった。加温 5 日後の

1）現在 農林水産省野菜・茶業試験場茶栽培部

2) Present address: Department of Tea Agronomy, National Research Institute of Vegetables, Ornamental Plants and Tea, Kanaya, Shizuoka 428, Japan.

日本応用動物昆虫学会誌 (応動昆) 第 32 巻 第 2 号: 143-146 (1988)

1987 年 10 月 14 日受領 (Received October, 14, 1987) 


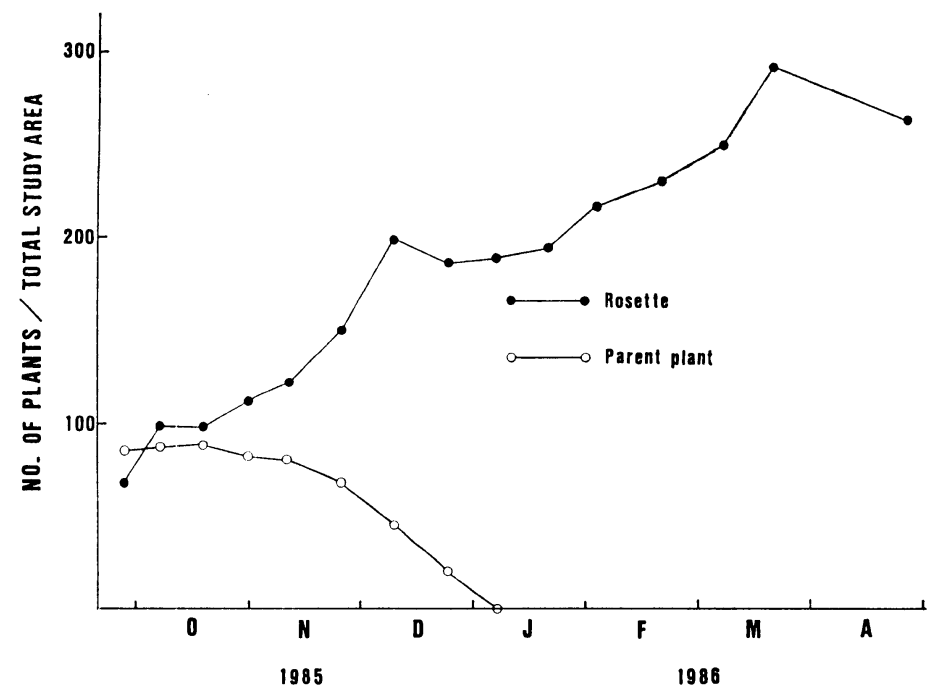

Fig. 1. Seasonal trend in the number of parent plants $(0)$ and rosettes $(\bullet)$ of goldenrod Solidago altissima L. per total study area.

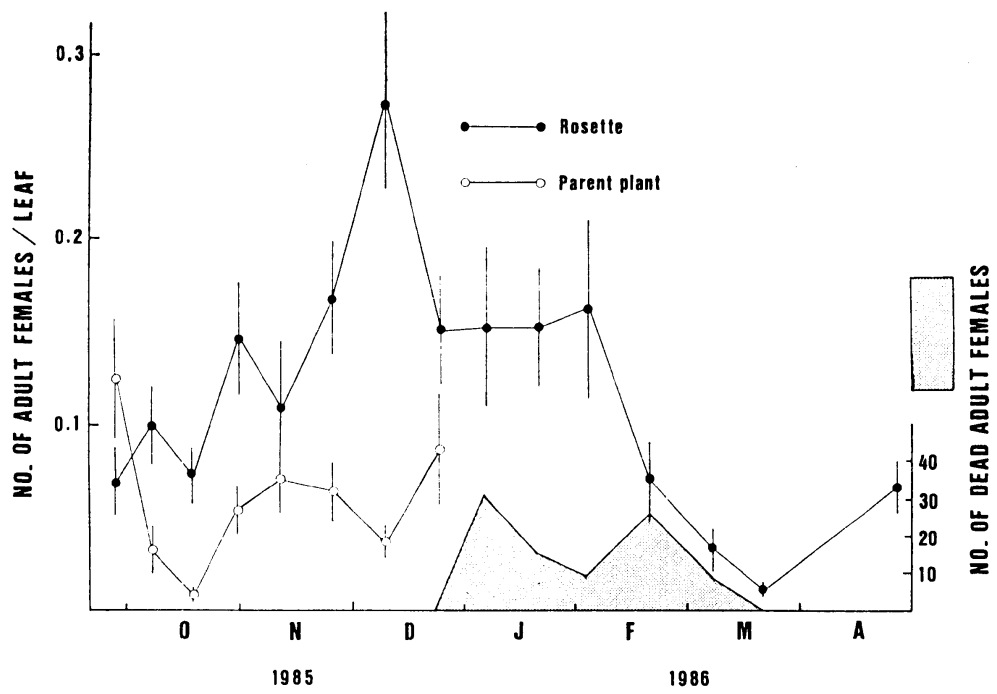

Fig. 2. Seasonal changes in population density of adult female $T$. desertorum on parent plants $(O)$ and rosettes $(\bullet)$. Vertical line indicates standard error.

産卵蓷率は常に $90 \%$ 以上であった (Fig. 5)。低温短日条件下で 発育した雌成虫にも体色の変化がまったくみられず産卵が継続 し，休眠個体はみとめられなかった。

\section{考察}

野外調查拉よび室内実験から本個体群住明らかに非休眠性で あり，雌成虫は親株が枯死するにつれて好適な慨資源である口 ゼットへ移動し，そこで冬季の個体群を維持している。また，
厳冬期のごく一時期を除けば，卵の生存率も高く維持されてい た。ちなみに，1月下旬でもロゼット茟上の気温は日中 $18^{\circ} \mathrm{C}$ から $20^{\circ} \mathrm{C}$ 程度まで上昇し, 本種は縓冬期でも産卵，吸汁を行 らと思われる。

JEPPSON et al. (1975) によれば, 北米南部の温暖地域ではア シノワハダニは冬季も各種の雑草に発生し，春季に綿花へ移動 後, 寄主変換をしていく。非休眠性のハダニが冬季, 雑草を餌 資源として個体群を維持する例は，ナシ園に 発生するナミハダ 
(a) PARENT PLANT

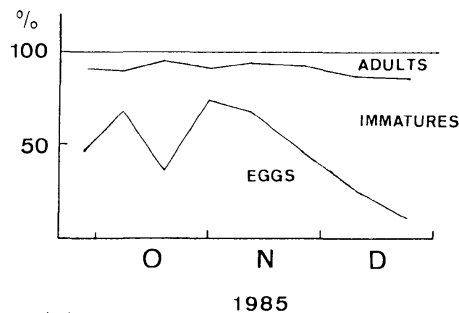

(D) Rosette adULTS

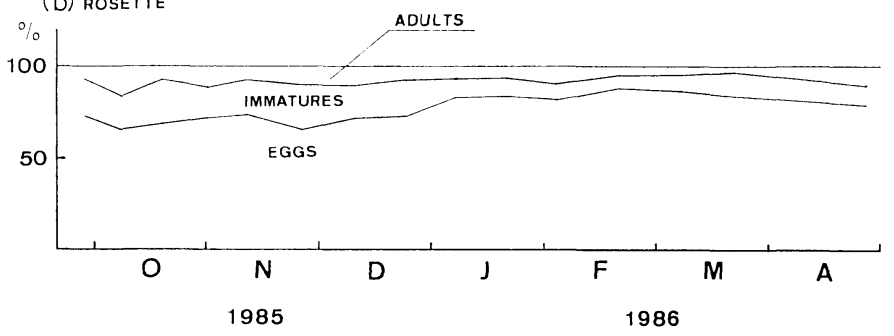

Fig. 3. Seasonal changes in the age distribution of $T$. desertorum on parent plants (a) and rosettes (b).

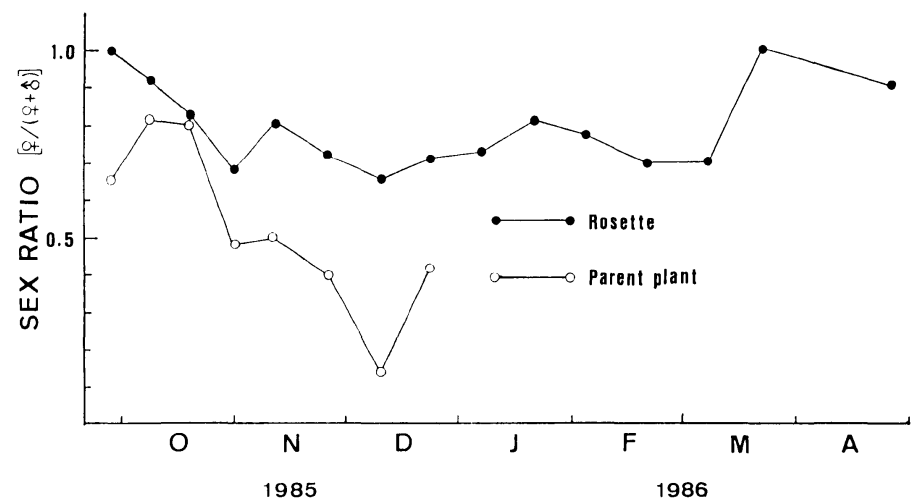

Fig. 4. Seasonal changes in the sex ratio $\left(\right.$ 우 $/\left(\right.$ 우 $\left.\left.+0^{7}\right)\right)$ of adults on parent plants $(0)$ and rosettes $(\bullet)$.

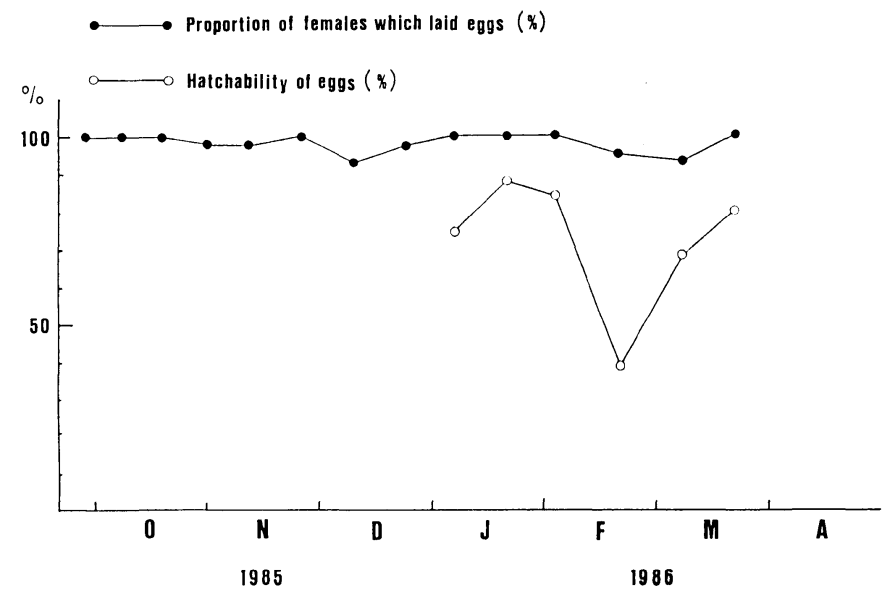

Fig. 5. Seasonal changes in the proportion of egg laying adult females $(\bullet)$ and the hatchability of eggs $(O)$ collected from rosettes. 
ニ Tetranychus urticae $\mathrm{KocH}$ でもみられ，園内の季節的に移り変 わる多数の雑草を利用している (TAKAFUJI and KAMIBAYASHI, 1984)。今回調查したアシノワハダニの個体群も基本的には，こ のような生活を営んでいる個体群の一つであろう。ただ，本調 查地では冬季間セイタカアワダチソウのロゼットが優占して繁 茂し，他の雑草はほとんどみられなかったことから，本個体群 にとってのセイタカアワダチソウのロゼットは生活環を維持す る上で主要な寄主植物と考えられる。
引用 文 献

後藤哲雄・真梶徳純 (1980) 応動昆 25: 113-118.

Jeppson, R., H.H. Keifer and E.W. BAKer (1975) Mites

Injurious to Economic Plants. Berkeley, Los Angeles, London: University of California Press, 614 p. 小林義明・深沢永光 (1981) 静岡農試研報 26: 21-34. Takafuji, A. (1980) Res. Popul. Ecol. 21: 197-216. Takafuji, A. and M. Kamibayashi (1984) Res. Popul. Ecol. 26: $113-123$.

\section{ヤマモモ果実を加害するショウジョウ バエの観察例}

\author{
行 成 正 昭
}

徳島県果樹試験場

Drosophilid Flies Injurious to the Fruits of Wax-Myrtle, Myrica rubra Sied et Zucc. Masaaki Yukinari (Tokushima Horticultural Experiment Station, Katsuura, Tokushima 771-43, Japan). Jpn. J. Appl. Ent. Zool. 32: 146-148 (1988)

ヤマモモ Myrica rubra SIEB. et ZUCC. (ヤマモモ科) は我国で は千葉県以南の太平洋沿岸 および福井県以南の日本海沿岸の暖 带地方に分布する常緑広葉樹である (高橋ら，1968)。徳島では ヤマモモの自生が多くみられ，古来から食味のよい系統を選ん で栽培もされ，1965 年には「県の木」に指定され一般の認識も 高まり, 今後, 徳島県の特産果樹として 発展に期待がよせられ ている。

この果実が生果あるいは加工して利用される過程で果実を加 害するショウジョウバェが問題となっている。そこでヤマモモ 果実を加害しているショウジョウバエの種類を明らかにする目 的で若干調查を実施した。

本文に入るに先だち，ショウジョウバエのすべての標本を同 定して下さり有益なご助言を賜わった成田豊日博士，ショウジ ヨウバエに関する文献や，ご教示いただいた 国立遺伝学研究所 渡辺隆夫博士，元岩手県園芸試験場小林森巳博士，本調查にあ たりご協力いただいた徳島県果樹試験場の和田英雄専門研究員 に厚くお礼を申し上げる。

\section{材料および方法}

徳島県果樹試験場内に植栽されているヤマモモ品種“森口”之 “瑞光”について，1986 年成熟期に近ついた頃から外観上無傷
とみられる果実をそれぞれ毎回 50 果ずつ 3 回採集した。すなわ ち“森口”は 7 月 4 日, 7 月 8 日, 7 月 11 日に, “瑞光” は 7 月 8 日，7月 11 日，7月 14 日に採集した。それらの果実は室 内で大型天敵飼育箱 (安松, 1963) に入れて保存し, 発育を完了 して羽化してくるショウジョウバェを捕捉し後日分類した。ヤ マモモはカンキツを 主体とした 当試験場ほ場の最上段に位置し た約 20a の傾斜面に植栽されてた㧍り, アカマツ等の雑木林が隣 接している。また, 当試験場本館前に植栽されているヤマモモ 孤立木 (品種 “与川内”) について, 地上に落下したヤマモモ果 実に群飛するショウジョウバエを 7 月 14 日に捕虫網で採集し, 後日分類した。

\section{結果および考察}

ヤマモモ樹上の果実 (生果) および落果からは第 1 表に示した 11 種のショウジョウバエの羽化が確認された。それらのなかで 樹上の生果を加害していたショウジョウバェは第 2 表に示した 6 種であった。Drosophila simulans が圧倒的に優勢で全体の 90.7\% を占めた。D. suzukii は 4.2\% と少なかったが, 熟期前 半には優勢種となっていた。一方，地上に落下した果実には 第 3 表に示したように 10 種の飛来が認められた。最も多かった のは D. immigrans で $63.1 \%$ を占めた。D. simulans $19.5 \%$ ， D. auraria $9.9 \%$ がこれに次いだ。D. suzukii \& $2.4 \%$ みられ た。D. busckii は樹上果だけにみられ，D. sordidula，D. lacertosa， D. sternopleuralis, Scaptomyza elmoi, Liodrosophila aerea は落果にの み認められたが，いずれも採集個体数がきわめて少なかった。 このように樹上の生果を加害するショウジョウバエは大部分落 果にも飛来を認めたが，それぞれの種の全体に占める割合が生 果と落果では異なっていた。

ところで D. suzukii は山形県でオウトウ果実を加害する種で あり(鈴木・庄司, 1979), 我国ではこの種だけがオウトウ，野 生のイチゴ (クサイチゴ, キイチゴ)，ブドウ，グーズベリー等 の生果に産卵管 (導卵突起) をさし込んで傷つけることが知られ

日本応用動物昆虫学会誌 (応動昆) 第 32 巻 第 2 号：146-148 (1988)

1987 年 10 月 28 日受領 (Received October 28, 1987) 